\title{
ECONOMIC IMPACT ANALYSIS OF STEEL INDUSTRY IN REPUBLIC OF MACEDONIA: THE CASE OF MAKSTIL A.D SKOPJE
}

\begin{abstract}
Darko Lazarov ${ }^{1}$
Assistant Professor at University Goce Delcev, Faculty of Economics - Stip, Republic of Macedonia Mitko Kocovski ${ }^{2}$

Makstil a.d Skopje and University of Tourism and Management - Skopje, Republic of Macedonia

Abstract: The main aim of the paper is empirical quantification of total economic impact of steel industry on Macedonian economy through the case of Maksil a.d-Skopje. The empirical quantification involves exploring the direct effects (the contribution of the Makstil to GDP, export, employment, taxes and corporate - social responsibility) and more important estimating the multiplicative effects (indirect effects through the chain of suppliers and induced effects by the stimulation of final household's consumption) that the Maktil a.d-Skopje as a largest company within the steel industry generates in the national economy by the reproduction processes. The economic impact methodology based on input - output model is applied to estimate the multiplicative effects. Furthermore, the empirical analysis of economic and financial indicators is done to capture the economic performance of Makstil a.d - Skopje. The type I output multiplier is 1.75. This indicates that for every denar increase in sales of Makstil a.d - Skopje, total output of the Macedonian economy increases by 1.75 denars, 1 denars is direct sales increase, another 0.75 denars arise from indirect or supply chain impacts. On the other side, the type II output multiplier is 2.1. This indicate that for every denars increase in production of Makstil a.d - Skopje, the total economic impacts is 2.1 denars (1.75 denars from direct and indirect or supply chain effects) and 0.35 denars contributed by induce or consumption effects. The estimated results indicate that the multiplicative effects (indirect and induced) of Makstil a.d - Skopje in terms of total value added is higher.
\end{abstract}

Key words: Economic impact analysis, input-output model, Makstil a.d - Skopje.

\section{INTRODUCTION}

The company Makstil AD - Skopje, as a main subject in the basic metal industry in the Republic of Macedonia, with its economic activities recently has had a significant positive impact on the Macedonian economy as seen through the prism of the generated job positions, the share in the GDP and the country's export, and the budget implications. At the same time, Makstil AD - Skopje is a significant generator of additional positive effects to the economy through stimulation of the production and employment in the supply chain of Makstil, as well as the

\footnotetext{
${ }^{1}$ darko.lazarov@ugd.edu.mk

${ }^{2}$ mitko.kocovski@makstil.com.mk
} 
generated consumption effects channelized through the salaries of the company's employees and the companies in the supply chain. The question is exactly how much is that economic impact (both direct and indirect) which the company, through the already elaborated transmission channels, generates on the national economy.

In that context, the aim of the study is to make a detailed presentation of Makstil AD - Skopje's profile through an analysis of the economic indicators and financial indices which depict the company's work and even more through quantification and empirical assessment of the influence and importance of the company in the national economy by stimulation of the direct impact and the implied multiplicative effects. The implementation and practical realization of the economic impact analysis of Makstil AD - Skopje for the Macedonian economy involves application of the wide-accepted quantitative methodology based on the use of the input-output model established on the "backward" industrial linkages.

Based on the elaboration of the subject and the aim of the study, it is consisted of two integral parts: 1) detailed observation of the company's profile since its beginning until today with explicit elaboration of the characteristics and economic specifics in the company's work through detailed observation of both the financial and economic indices; and 2) economic impact analysis which will allow quantification and assessment of the direct influence that Makstil generates on the economy through its relative share in the GDP (market value of the final goods and services), the industrial production and the export of goods and services by the Republic of Macedonia, and more importantly, assessment of the multiplicative effects generated through the supply chain of the company (with its economic activity, Makstil stimulates the work and existence of many companies in the country as its suppliers) and through the final consumption of the employees in Makstil and those in its supply chain.

\section{THEORETICAL REVIEW OF THE INPUT - OUTPUT MODEL}

The (I/O) model provides means to capture and measure the economic effects of the industry's activities to the national economy. It uses three effects to measure economic impact: direct, indirect and induced effects, Richardson (1985).

- Direct effects refer to production change associated with a change in demand for the good itself. It is the initial impact to the economy, which is exogenous to the model. 
- Indirect effects refer to the secondary impact caused by changing input needs of directly affected industries (e.g., additional input purchases to produce additional output).

- Induced effects are caused by changes in household spending due to the additional employment generated by direct and indirect effects.

The assessment of the multiplicative effects of steel industry to the national economy includes the estimation of several multipliers such as: output multiplier (every dollar change in direct output caused changes in the total value of output in all sectors), employment multiplier (every dollar change in direct output caused changes in number of jobs in the economy), personal income multiplier (every dollar change in direct output caused changes in income received by households), and business taxes multiplier (every dollar change in direct output caused changes in indirect business taxes), Miller and Blair (1985).

The input - output model assumes a linear production function, which means constant returns to scale and constant production functions for each firm within an industry, Grady et al. (1988). For example, the model assumes that a small mill would use the same inputs, in the same proportion, as large production mill. Furthermore, the model assumes that the percentage of those inputs that are purchased locally is constant from one firm to the next, Mills (1993). The input-output models incorporate several important assumptions, Hughes (2003): 1) Output is also assumed to be homogenous. In other words, the assumption is that the production mills would produce the same percentage of lumber, wood chips, and other outputs; 2) It assumes that there are no constraints on the supply of any commodity; 3) It assumes that increases or decreases in employment cause in- or out-migration from the state modeled, so that "full employment" is maintained.

I-O model organize producers into $n$ industries, where businesses in an industry are assumed to use the same production process. Each industry i produces gross output, $X_{i}$, which is measured in dollars. This output is sold to industries $j$ as intermediate inputs, $z_{i j}$, or to final users, $Y_{i}$.

$$
X_{i}=z_{i 1}+z_{i 2}+z_{i 3}+\ldots+z_{i n}+Y_{i}
$$

The above equation shows how I-O models assume that production takes place under strict linear conditions. A set of relationships called "technical coefficients," $\mathrm{a}_{\mathrm{ij}}$ are defined as $a_{i j}=z_{i j} / X_{j}$.

Each coefficient shows how much of industry i's output is needed to produce a dollar of output in industry $j$. These coefficients show how 
I-O models assume that industries always use the same proportions of inputs to produce output.

\subsection{The supply chain of Makstil AD - Skopje}

The supplier chain which directly or indirectly is involved in the production process of primary steel in the Republic of Macedonia is fairly wide and includes many goods and services. The machinery, operating supplies, and different types of services are an integral part of the production process of Makstil AD - Skopje.

Considering the scope of the steel industry in the Republic of Macedonia, it is impossible and economically unprofitable to create a sector for machinery production for the steel industry, and that is why Makstil AD - Skopje is forced to obtain the technology and machinery from foreign companies. Contrary to the technical services for maintenance and mending, there is a significant specific by which the industry for primary steel (Makstil AD - Skopje) differs from the other industries. Particularly in the company, there is a sector for maintenance and mending that takes care of removing defects and making reparations, contrary to the other steel companies from the world, which hire outsourcing services.

The analysis of the expenses structure indicates that the biggest relative share involves the expenses for raw materials and other materials (such as iron, oils, lubricators, spare parts, expenditures of chattels), $51 \%$ and $60 \%$ in 2007 and 2014, respectively.

The energy and energetic materials (electricity and natural gas) represent second input and expense in the company production. Namely, the relative share of the energetic materials in the production is nearly $27 \%$ and $23 \%$ in 2007 and 2014, respectively. Also here may be found the nature of the smaller relative share of energy in the expenses structure of the company in 2007 with regard to 2014 in the abovementioned explanation, due to the fact that the slabs production through the melting of the old iron in an electric arc furnace in the steel-mill is energetically more intensive production process.

The transportation (by truck and train) and the related expenses were of marginal significance in the expenses structure $(0,3 \%$ and $0,64 \%$ in 2007 and 2014, respectively) due to the fact that the transportation expenses of the deliveries are taken care of by the buyers, and the only company expense is the internal transportation. 
Economic impact analysis of steel industry in Eepublic of Macedonia: the case...

Table 1.: Relative share of intermediate inputs and expenses

\begin{tabular}{|c|c|c|}
\hline $\begin{array}{c}\text { Structure of intermediate inputs and } \\
\text { expenses of production }\end{array}$ & $\mathbf{2 0 0 7}$ & $\mathbf{2 0 1 4}$ \\
\hline Expenses for raw materials and other materials & $51 \%$ & $60 \%$ \\
\hline Services & $8,5 \%$ & $6,3 \%$ \\
\hline Intangible expenses & $9,3 \%$ & $3 \%$ \\
\hline Energy and energetic materials & $27,2 \%$ & $23,4 \%$ \\
\hline Transportation expenses & $0,3 \%$ & $0,6 \%$ \\
\hline Depreciation & $2,5 \%$ & $5,9 \%$ \\
\hline
\end{tabular}

Source: Calculation by the authors based on the data from Makstil AD - Skopje balances.

The intangible expenses which cover the expenses for transport, food and severance pay, banking services, insurance premiums, daily travelling allowances, and other types of intangible expenses in 2007, had a relative share of $9.2 \%$ from the total expenses, so that this type of expenses mark a significant reduction to $3 \%$ of the total expenses of the company in 2014.

The services also mark a decreasing trend in the absolute and relative amount of the company expenses (from 8, 5\% in 2007 it was cut to $6,3 \%$ in 2014), however, they hold a tendency of significant decrease in absolute amount. Namely, the company regarding the services (banking, telecommunication, shipping, rents, marketing and advertising services, sponsorships, postal, and other types of services) in 2007 spent an amount of 480.307.346 denars, while this amount in 2014 was cut to 250.401 .033 denars.

Picture 1.: Relative share of intermediate inputs and expenses

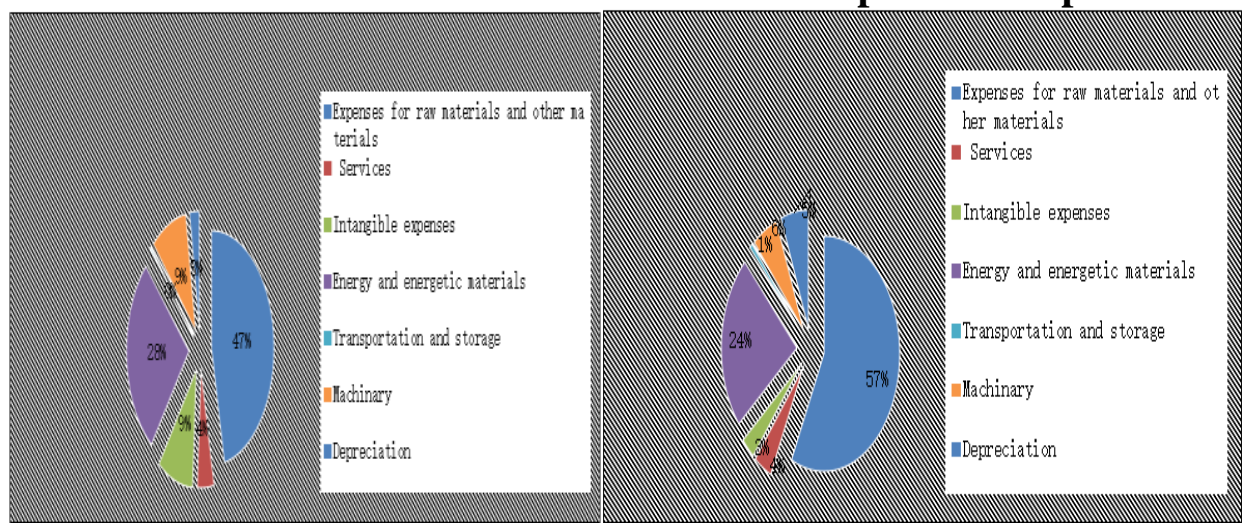

Vol. 18, бpoj 2/2016, cmp. 13-27 
The matter that probably attracts more attention, when it comes to the expenses analysis, is the study of the sensitivity of different categories of expenses regarding the change in production and incomes of the company's work. In other words, let us study how different categories of expenses react to the changes in production and incomes.

The results from the empirical analysis of the expenses, production and incomes show that the most sensitive category of expenses is the intangible expenses. Namely, the total production of steel slab and thick plate expressed in subsistence value marked a cut for $86 \%$ in 2014 regarding 2007, and in the same period, the company incomes dropped for $50 \%$. As a reaction of the decrease in production and the company incomes, the services and the intangible expenses are reduced for $94 \%$ and $337 \%$, respectively. Consequently, the flexibility ratio shows that each decrease of production and incomes for $1 \%$ will cause decrease of services for $1.8 \%$ and $1.06 \%$, respectively. On the other hand, the decrease of production and incomes for $1 \%$ will cause decrease of the intangible expenses for $6.7 \%$ and $3.9 \%$, respectively.

\section{ECONOMIC IMPACT ANALYSIS OF MAKSTIL AD - SKOPJE}

At this segment of the study through usage of the economic impact analysis, we will quantify the meaning and the multiplicative influence which Makstil AD - Skopje generates through its supply chain, employees and the other subcontractors for the total economy. Namely, Makstil $\mathrm{AD}$ - Skopje with a total average annual gross value of production and retail of 4.373.134.765 denars in the period 2000-2014 generated a total gross value of $\mathbf{6 5 . 5 9 7 . 0 2 1 . 4 7 5}$ denars, which only represents a clear evidence and affirmation of the role and meaning which this subject has within the national economy.

In order to meticulously and explicitly quantify the direct impact of the company on the national economy, we will analyze the most synthetic indices which regard the number of employees, taxes, relative share in the gross added value of the processing industry, GDP and the total exports of the county. The relative direct share of the total added value (the contrast between the gross value of the products and betweenphase consumption which varied from 426 million denars in 2000 to maximum amount of 790 million denars in 2007, or an average of 673 million denars in the analyzed period) of Makstil AD - Skopje, in the total added value of the processing industry's GDP (market value of the final goods and services) of the country, amounts to $1.39 \%$ and $0.23 \%$, respectively in the period 2000-2012. 
Table 2.: Gross added value of Makstil a.d Skopje, in mill. denars

\begin{tabular}{|c|c|c|c|c|c|}
\hline Year & $\begin{array}{c}\text { Gross added } \\
\text { value - Makstil, } \\
\text { Millions of denars }\end{array}$ & $\begin{array}{c}\text { GDP in } \\
\text { millions of } \\
\text { denars }\end{array}$ & $\begin{array}{c}\text { Relative } \\
\text { percentile } \\
\text { share, \% }\end{array}$ & $\begin{array}{c}\text { Processing } \\
\text { industry, } \\
\text { millions of } \\
\text { denars }\end{array}$ & $\begin{array}{c}\text { Relative } \\
\text { percentile } \\
\text { share, \% }\end{array}$ \\
\hline 2005 & 728 & 264847 & 0.27 & 43627 & 1.67 \\
\hline 2006 & 791 & 291105 & 0.27 & 49627 & 1.59 \\
\hline 2007 & 790 & 321378 & 0.25 & 64083 & 1.23 \\
\hline 2008 & 785 & 357150 & 0.22 & 70634 & 1.11 \\
\hline 2009 & 623 & 358369 & 0.17 & 57628 & 1.08 \\
\hline 2010 & 652 & 377201 & 0.17 & 54756 & 1.19 \\
\hline 2011 & 735 & 399376 & 0.18 & 61918 & 1.19 \\
\hline 2012 & 687 & 403684 & 0.17 & 49516 & 1.39 \\
\hline Average & $\mathbf{6 7 3}$ & $\mathbf{2 9 8 . 8 8 9}$ & $\mathbf{0 . 2 3 \%}$ & $\mathbf{4 9 . 8 5 2}$ & $\mathbf{1 . 3 9 \%}$ \\
\hline
\end{tabular}

Source: Calculation by the authors based on the data from Makstil AD - Skopje balances.

The relative share of Makstil's export in the amount of the total export of the country is significantly bigger compared to the share in the gross added value of the company in the added value of the processing industry and the country's GDP. Namely, Makstil AD - Skopje, as one of the biggest Macedonian exports recently, with an average amount of exports of $\mathbf{3 . 5 1 1}$ million denars, has a relative percentile share in the total export of the country of $2.79 \%$ in the analyzed period. Considering that $75 \%$ of the inputs that Makstil employs in the domestic economy, we can conclude that the net export of Makstil is significant compared to some companies that have bigger percentile share in the export, but at the same time they have small value of the net export due to the big percentile share of the imported foreign inputs.

Table 3.: Export value and the relative percentile share, in mill. denars

\begin{tabular}{|c|c|c|c|}
\hline Years & $\begin{array}{c}\text { Total export - } \\
\text { Makstil }\end{array}$ & National export & $\begin{array}{c}\text { Relative percentile } \\
\text { share, \% }\end{array}$ \\
\hline 2007 & 4147 & 164507 & 2.52 \\
\hline 2008 & 4911 & 179334 & 2.74 \\
\hline 2009 & 3599 & 136019 & 2.65 \\
\hline 2010 & 4906 & 173999 & 2.82 \\
\hline 2011 & 5652 & 218745 & 2.58 \\
\hline 2012 & 4072 & 211764 & 1.92 \\
\hline Average & $\mathbf{3 . 5 1 1}$ & $\mathbf{1 3 0 . 9 5 6}$ & $\mathbf{2 . 7 9 \%}$ \\
\hline
\end{tabular}

Source: Calculation by the authors based on the data from Makstil AD - Skopje balances. 
Picture 2.: Total value of export and the relative percentile share, in mill. denars

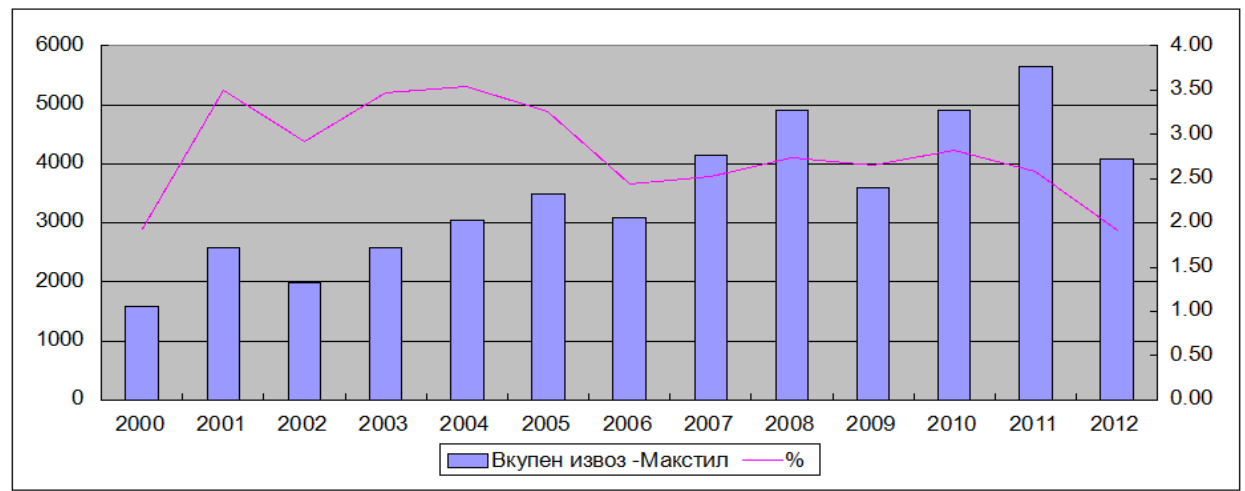

In the last few years, the number of employees in Makstil AD Skopje has varied from 850 to 950 employees (the employees' structure is dominated by qualified manpower according to the needs of the production process of the company), whereupon the factor income of labour (the total amount of salary and other benefits which the company paid to the employees) is 396.951.111 and 306.488.631 denars in 2007 and 2014, respectively. The chart shows the number of employees in Makstil AD - Skopje according to the level of education and qualifications.

If we analyze the average salary in the analyzed period, we will see that the average salary in Makstil AD - Skopje is bigger than the average salary in the national economy. Namely in 2007, the average number of employees, according to the estimated work hours, hired by the company, amounts to 852 employees, regarding the total number of employees in the whole industry which at the same period amounts to 184.928 employees, whereupon the average gross salary that Makstil AD - Skopje paid in 2007 is 38.825 denars, regarding the average gross salary in the whole industry, which was 24.500 denars, while the average net salary which Makstil AD - Skopje paid was 24.130 denars, regarding the average net salary in the whole industry, which was 15.000 denars.

In 2014, the number of employees and the average salary in Makstil AD - Skopje marked a tendency of decrease (the average number of employees was 790, while the average net salary was 22.000 denars, regarding the average net salary within the whole industry, which was 22.600 denars) due to the decreased economic activity of the company, that was as a result of the investment activities for meeting the ecostandards that prevented the regular work and production of the company, and also it was as a result of the bad economic situations caused by the 
world crises which can still be felt in the EU countries where Makstil AD - Skopje exports most of its products.

The total added value which assesses the company's contribution to the national economy, as seen through the prism of the factor income of the labour (employees' salary), the capital income (depreciation and profit of the company) and the indirect taxes (VAT and duties) varies from $\mathbf{2 6 7}$ million denars in 1998 to $\mathbf{6 3 0}$ million denars in 2014, with the highest amount of near 800 million denars marked in 2006 and 2007. In relative perspective, the percentile share of the gross added value in the total company income varies from $11.2 \%$ in 1998 to $14.2 \%$ in 2014 , with the highest percentage of $31 \%$ realized in 2002 .

\section{Picture 3.: Total added value (absolute and relative income, \%) and} (in mill. denars)

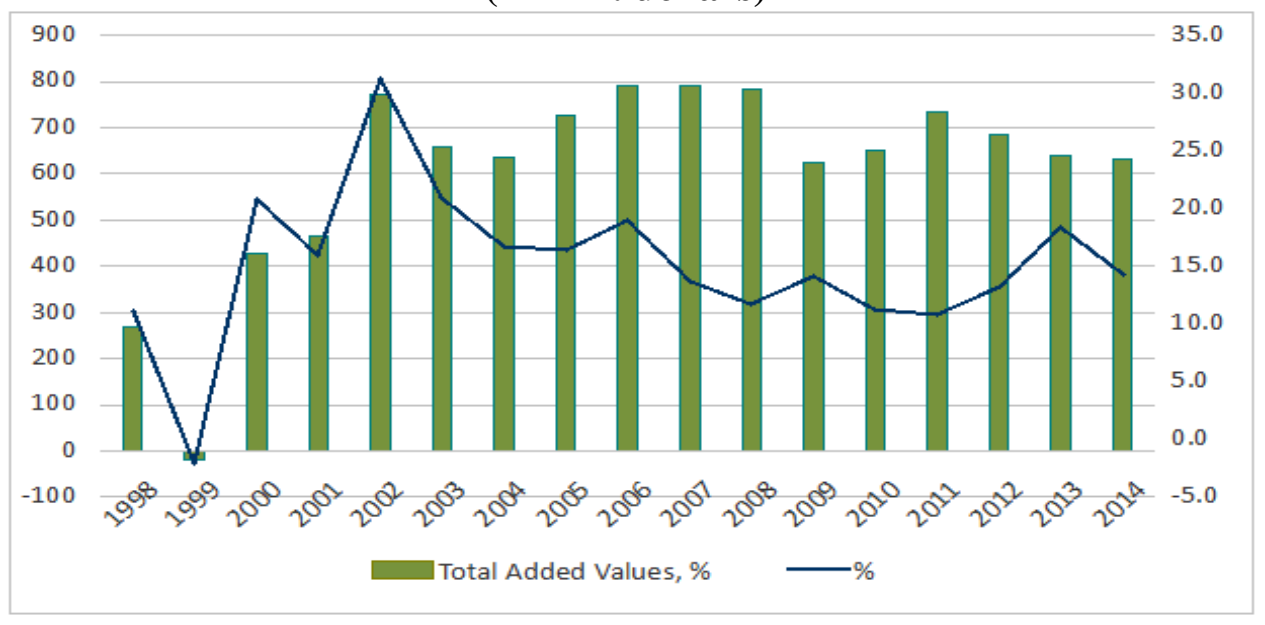

The positive impact which Makstil AD - Skopje generates in the national economy can be analyzed through the taxes (both direct and indirect) which the company pays to the country, social and pension security for its employees, duties and other types of duties, property tax, business tolls for licenses, licenses, and etc.

Below, the given chart presents the budget effects from the company's work through the taxes which are paid in the country in different forms (tax profit, social and pension security for the employees, fees for occupation with an early retirement and other fees, employees' personal tax).

In 2007, Makstil AD - Skopje paid 150.259.633 denars for personal tax; 14.556 .942 denars for social and pension security for the employees, fees for occupation with an early retirement and other fees, and 24.033.522 denars for tax profit (a total of 188.850.097 denars), 
while in 2014, Makstil AD - Skopje paid the country 98.290.744 denars for personal tax, 9.164.862 denars for social and pension security for the employees, fees for occupation with an early retirement and other fees, and 578.275 denars for tax profit (a total of 108.033.881 denars).

Table 4.: Value of export and the relative percentile share, in mill. Denars

\begin{tabular}{|c|c|c|}
\hline TAXES & $\mathbf{2 0 0 7}$ & $\mathbf{2 0 1 4}$ \\
\hline $\begin{array}{c}\text { Personal tax, social and pension security } \\
\text { for the employees. }\end{array}$ & 150.259 .633 & 98.290 .744 \\
\hline $\begin{array}{c}\text { Fees for occupation with an early } \\
\text { retirement and other fees. }\end{array}$ & 14.556 .942 & 9.164 .862 \\
\hline Tax profit & 24.033 .522 & 578.275 \\
\hline TOTAL & 188.850 .097 & 108.033 .881 \\
\hline
\end{tabular}

Source: Calculation by the authors based on the data from Makstil AD - Skopje balances.

What should also be taken into consideration in the analysis of the company's direct economic impact on the national economy are the positive externalities which the company through its work creates in the economy with the contribution in the country's balance of payment, the corporate-social responsibility, ecology and investments for protection of the environment, social dimension for the collectors of old iron and other positive effects that Makstil AD - Skopje generates through its work.

Namely, when it comes to the corporate-social responsibility of Makstil AD - Skopje, it is important to say that in the past period, the company by direct or indirect funding of many sports clubs and sportspeople in the country, by awarding scholarships, supporting research projects connected with the metallurgy and economy, by ensuring help and support for other cultural manifestations and events, has a significant role in the socio-economic life in the country.

\subsection{The multiplicative effects of Makstil AD - Skopje}

What is more important for this study is the question how much Makstil AD - Skopje, indirectly through its work, encourages the production, added value, and employment in the national economy through the multiplicative effects (both indirect and induced). On the picture below, there is a general overview of the economic multipliers which Makstil AD - Skopje generates in the national economy based on the empirical analysis and research carried out in the study. For each growth of the production and retail of Makstil AD - Skopje for one 
denar, the total output of the Macedonian economy will increase for $\mathbf{2 , 1}$ denars; one denar is the direct impact, the additional growth of the output for 0,75 denars is the result of the indirect impact through stimulation of the output of the firms in Makstil's chain supply, and the rest of the growth of the total output of 0,35 denars is generated through the induced influence which is evident in the additional expenditure in the economy by the employees in Makstil and the employees in Makstil's chain supply, and through the expenditures of the capital owners in Makstil and its chain supply.

If we take into consideration the company's total value of production and retail, which annually on average is 4.373 million denars in the analyzed period, then we can establish that through its multiplicative effects Makstil triggers additional production in the economy of $\mathbf{9 . 1 8 3}$ million denars or a total of $\mathbf{1 3 . 5 5 8}$ million denars per year.

Table 5.: Multiplicative effects of Makstil a.d Skopje

\begin{tabular}{|c|c|c|c|c|c|c|}
\hline Multiplier & Direct & Indirect & Induced & Total & Type I* & Type II* \\
\hline Output & 1.00 & 0.75 & 0.35 & 2.10 & 1.75 & 2.10 \\
\hline $\begin{array}{l}\text { Factor income } \\
\text { of labor }\end{array}$ & 0.090 & 0.14 & 0.18 & 0.31 & 2.11 & 4.55 \\
\hline Employment & 1.00 & 2.50 & 2.00 & 4.50 & 2.50 & 4.50 \\
\hline Added value & 0.152 & 0.220 & 0.350 & 0.720 & 2.45 & 4.75 \\
\hline \multicolumn{7}{|c|}{ Employment or taxes in millions of denars for the total output } \\
\hline Employment & \multicolumn{2}{|c|}{6.67} & & & & \\
\hline Total taxes & \multicolumn{2}{|c|}{32,756} & & & & \\
\hline
\end{tabular}

Multiplier Type I shows that the growth of the production and retail of Makstil for $\mathbf{1}$ denar generates growth in the total output in the economy for $\mathbf{1 . 7 5}$ denars, while the Multiplier Type II shows that the growth of the production and retail of Makstil for 1 denar generates total economic impact of $\mathbf{2 . 1}$ denars.

The general overview of the economic multiplicative effects which Makstil AD - Skopje generated in the Macedonian economy will be decomposed through observing the respective multipliers in the total added value, taxes, employment, factor income of labour. The report for the employment multiplier assesses the direct effect in generating job positions through the number of employees in Makstil by millions of denars for the total output. For each one million denars of final output, 
Makstil AD - Skopje directly creates 6.67 job positions which simply show the employment rate in the company. Above we saw that the number of employees in the company is around 900 employees, which de facto assesses the direct impact of the company.

Furthermore, the number of employees that Masktil AD - Skopje indirectly creates in the economy through the supply chain is around 2225 employees (the indirect multiplier for the employees is 2.5) and through the induced effects which refer to the expenditures of the employees in Makstil AD - Skopje and its supply chain which amounts of around 1780 employees (the induced multiplier for the employees is 2).

The total number of employees that Makstil AD - Skopje directly or indirectly creates in the national economy is around $\mathbf{4 7 8 5}$ employees, according to our assessments.

Picture 4.: Multiplicative effects in the employment

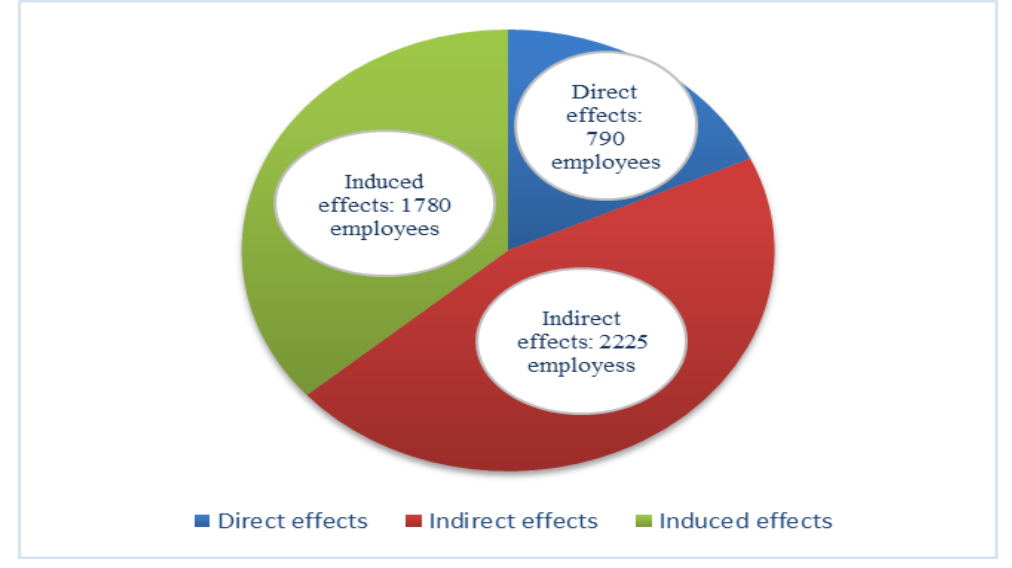

When it comes to the multipliers in the total added value, the results from the analysis show that Makstil AD - Skopje additionally through the indirect and induced effects generates and triggers creation of extra additional value in the economy of $\mathbf{9 2 5}$ million denars and $\mathbf{1 . 4 7 2}$ million denars, respectively. Based on this estimations, the total gross added value which Makstil AD - Skopje generates in the economy, directly or through its multiplicative effects, is $\mathbf{3 0 7 0}$ million denars on average per year in the analyzed period, which quantified in the relative dimension, as an attributive share in the processing industry and GDP of the country, is $6,15 \%$ and $1,03 \%$, respectively.

The biggest multiplicative effect of the total supply chain of Makstil AD - Skopje, regarding the total added value, is included in the sector for collecting old iron, the sector for production, transmission and distribution of natural gas and electricity, and the sector for services. 
Picture 5.: Multiplicative effects in the total added value

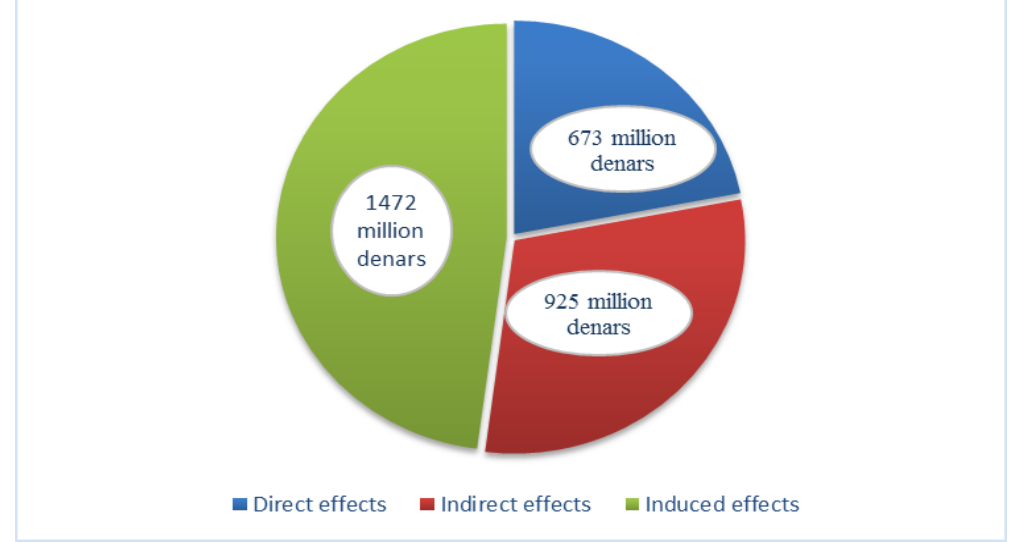

\section{CONCLUSION}

The main aim of the economic study and impact analysis of Masktil AD - Skopje, as the most significant subject in the steel industry of the Republic of Macedonia, is a detailed presentation of its profile through historic and fact-finding revision connected with the company, and through analysis of the production performances, economic indicators and financial indices which depict its work and distinctions, and even more, through the quantification and empirical assessment of the influence and importance of the company for the national economy through stimulation of the direct impact and induced multiplicative effects that the company generates in the economy through its work.

Makstil AD - Skopje with a total average annual gross value of the production and retail of 4.373.134.765 denars, in the period from 2000 to 2014 (it should be from 1998), generated total gross value of 65.597.021.475 denars or equivalent of around billion euros, which only shows clear evidence and confirmation of the role and the meaning that this subject has within the national economy.

The relative direct share of the total added value (the difference between the gross value of products and between-phase expenditure which varied from 426 million denars in 2000 to the highest amount of 790 millon denars in 2007 or it was 673 million denars on average in the analyzed period) of Makstil AD - Skopje in the total added value of the processing industry and GDP (market value of the financial goods and services) of the country is $1.39 \%$ and $0.23 \%$ respectively in the period 2000-2012.

The relative share of Makstil's export in the value of the total export of the country is significantly bigger compared to the share of the gross added value of the company in the added value of the processing 
industry and country's GDP. Namely, Makstil AD - Skopje, as one of the biggest Macedonian exporters in the last period, with an average export value of $\mathbf{3 . 5 1 1}$ million denars, has a relative percentile share in the total export of the country of $2.79 \%$ in the analyzed period. (Data for the export value in the last few years should be included, based on the percentage that has been calculated).

What is more important for this study is the question how much Makstil AD - Skopje indirectly through its work encourages the production, added value, employment in the national economy through the multiplicative effects (both indirect and induced). The decomposing of the multiplicative effects (both indirect and induced) allow the creation of a detailed picture for the overall influence and meaning of the company for the national economy as seen through the prism of the extra production, job positions, added value, and taxes generated through the supply chain and the induced effects.

Multiplier Type I shows that the growth of the production and retail of Makstil AD - Skopje for $\mathbf{1}$ denar generates growth of the total output in the economy for $\mathbf{1 . 7 5}$ denars, while the Multiplier Type II shows that the growth of the production and retail of Makstil AD Skopje for 1 denar generates a total economic impact of 2.1 denars. If we consider the total value of the production and retail of the company, which is $\mathbf{4 . 3 7 3}$ denars on average per year in the analyzed period, then we can establish that through its multiplicative effects Makstil AD Skopje triggers additional production in the economy of 9.183 denars or a total of $\mathbf{1 3 . 5 5 8}$ denars per year.

Furthermore, the number of employees that Makstil AD - Skopje indirectly creates in the economy through the supply chain is around 2225 employees (the indirect multiplier for the employees is 2.5) and through the induced effects, referring to the expenditures of the employees in Makstil and its supply chain, that number is around 1780 employees (the induced multiplier for the employees is 2). The total number of employees that Makstil AD - Skopje directly or indirectly creates in the national economy is around $\mathbf{4 7 8 5}$ employees, according to our estimations.

\section{REFERENCES}

1. Choong-Ki, Lee and Tracy Taylor. 2005. Critical reflections on the economic impact assessment of a mega-event: the case of 2002 FIFA World Cup.Tourism Management 26(4): 595-603.

2. Fletcher E. John. 1989. Input-output analysis and tourism impact studies. Annals of Tourism Research 16(4): 514-529. 
3. Guy R. West. 1995. Comparison of Input-Output, Input-Output + Econometric and Computable General Equilibrium Impact Models at the Regional Level. Economic Systems Research7(2):209-227.

4. Grady, Patrick and R. Andrew Muller. 1988. On the use and misuse of input-output based impact analysis in evaluation. The Canadian Journal of Program Evaluation 12(3): 49-61.

5. Hall, Robert E. 2009. By how much does GDP rise if the government buys more output? NBER Working Paper.

6. Hughes, David W. 2003. Policy uses of economic multipliers and impact analysis.Choices: Publication of the American Agricultural and Economics Association.

7. Isard, Walter. 1953. Some empirical results and problems of interregional input-output analysis: In Studies in the structure of the American economy. New York: Oxford University Press.

8. Oosterhaven Jan. 1998. on the plausibility of the supply-driven input-output model.Journal of Regional Science 28(2): 203-217.

9. Kahn, R.F. 1931. The relation of home investment to unemployment. The Economic Journal 41(162):173-198.

10. Lave Laster, Hendrikson Elisa, and McMicheal Francis. 1995. Using Input-Output Analysis to Estimate Economy-wide Dischar. Environmental Science. Technology 29(9): 420-426.

11. Leontief, Wassily. 1941. The structure of the American economy. Cambridge, Massachusetts: Harvard University Press.

12. Miller, Ronald E. and Blair D. Peter D.2009. Input-Output Analysis: Foundations and Extensions. New York: Cambridge University Press.

13. Mills, Edwin C. 1993. The Misuse of Regional Economic Models. Cato Journal 13(1): 29-39.

14. Richardson, Harry, W. 1985. Input-output and economic base multipliers: Looking backward and forward. Journal of Regional Science 25(4): 607-662.

15. Siegfried, John, Allen R.Sanderson, and Peter McHenry. 2006. The economic impact of colleges and universities. Working Paper 06-W12. 
